vants, for the British government to adopt the Steam Generating Heavy Water Reactor (SGHWR) as the next step in the British nuclear power programme. $\mathrm{Mr}$ John Lyons, deputy general secretary of the IPCS, says that electricity generation would be cheaper and export potential higher if the SGHWR were adopted instead of the Advanced Gas Cooled Reactor (AGR) which the British government is at present supporting.

The Department of Trade and Industry is studying the next step in an official committee. The question is whether to continue with the AGR or to adopt the SGHWR. The committee is also considering whether the High Temperature Reactor (HTR) or the American light water reactor could be used as the basis of British nuclear power generation until the fast reactor, now under development, is phased in. $\mathrm{Mr}$ Lyons dismisses the possibility of using the American light water reactor as, in his view, the British reactors are better than their American counterparts.

The HTR on the other hand is the reactor actively under consideration in Britain as the next step after the AGR. Its development is, however, seven or eight years behind that of the SGHWR, now ready to go into production. The decision therefore boils down to whether to continue building AGRs until the HTR becomes a practical possibility-and there is no guarantee of this-or to abandon the AGR and base the British nuclear programme on the SGHWR for the next ten years. $\mathrm{Mr}$ Lyons emphasizes that a decision to adopt the SGHWR would not mean relinquishing the HTR and he says that development work should continue.

The reasons for replacing the AGR by the SGHWR are, according to $\mathrm{Mr}$ Lyons, three-fold. First, the capital cost and cost of electricity generation by the SGHWR will be substantially less than that of the AGR. Second, the SGHWR is better able to follow the demand for electricity and simpler to construct and maintain. It also produces more plutonium-an important factor for the fast reactor programme. Third, the SGHWR has a high export potential whereas the AGR has none.

$\mathrm{Mr}$ Lyons points out that the decisive factor which should make the committee recommend the SGHWR is its export potential. It remains a sore point that Britain has only exported two nuclear power reactors-both of them of the Magnox type. Mr Lyons argues that once a country has invested in a water reactor, it is more likely to continue with a similar type. Thus the SGHWR is more likely to be sold abroad than the AGR which Britain has completely failed to export so far.

Mr Lyons also demonstrates his lack of faith in the British ability to maintain its two-year lead in fast reactor development by saying that when the time comes for Britain to export its fast reactors, the Americans and Europeans will have caught up, and unless Britain has a footing in the export market by then it will be severely handicapped.

The Central Electricity Generating Board has so far snubbed the SGHWR although, according to Mr Lyons, the chairman, Sir Stanley Brown, has acknowledged its suitability. The CEGB has opted for the HTR to follow the AGR because it is more likely to have an edge over the SGHWR in the larger reactors that the CEGB will need. Also part of the argument for continuing with the AGR for the next few years is that the CEGB staff are trained in gas reactors and that the introduction of a water reactor would mean acquiring a new technology.

\section{HOVERCRAFT Liff-off}

from a Correspondent

STATIC tests are now under way on Britain's hovertrain after four years of development by Tracked Hovercraft Ltd. Running tests will be made on the mile long track at Earith near Cambridge in a few weeks' time.

Two British developments form the basis of the hovertrain. The jet air cushions supporting the hovercraft were pioneered by Sir Christopher Cockerell and the propulsion system is a single sited linear induction motor invented by Professor Eric Laithwaite of Imperial College, London. The combination of hoverpads and linear motor will allow operational speeds of up to $300 \mathrm{mph}$. The propulsion system itself is quiet and the noise from the air pad fans is not excessive, although at present the RTV 31 test vehicle is fitted with unsilenced fans so that noise sources can be easily located. A progressive noise reduction programme is aiming at $90 \mathrm{db}-$ comparable to a heavy lorry - as an acceptable noise level. The test vehicle is remotely controlled with the equipment on board telemetered by the control centre. A second experimental craft is nearing completion and the two vehicles will be used for future development of the suspension, propulsion and guidance systems.

A further grant of $£ 1.75$ million in addition to the $£ 3.6$ million already loaned to THL was confirmed by the British Government in September and this will allow the extension of the elevated track from three to eight miles so that speeds of $250 \mathrm{mph}$ should be reached by the end of 1972 .

Interest in the hovertrain is rapidly increasing. Within the past month the United States Department of Transportation has officially endorsed the
British system for the congested northeast corridor-the Washington-New York-Boston run. Tracked Hovercraft Ltd is convinced that the key factor in the cost of hovertrain systems, which are also being developed in France and the USA, is the cost of the track. The American system uses a U-shaped trough whereas the British system uses a simple box beam and cost analysis of the two systems showed the THL system to be cheaper by 20 per cent-a saving of $\$ 700$ million over the projected route. The department's report recommended that planning of the route should begin immediately and that the decision on which system to use should be made in 1976 .

THL has also studied the possibilities of hovertrain links between London and Foulness, Gatwick and Heathrow, and between London and Liverpool. It estimates the cost over a 200 mile run, including stations, vehicles, construction and land acquisition, to be appreciably under $£ 1$ million per mile, the cost of motorways. A commercial application of the hovertrain would operate on pylons spaced up to 150 foot apart and 25 to 30 foot off the ground which eases the cost of land acquisition and causes less disruption than motorways. THL also estimates that the service could be run at a 10 per cent return on capital invested at rates between British Rail's first and second class fares.

THL claims, and the rest of the world appears to be beginning to agree, that its system is faster, quieter, cheaper and simpler than its French and American rivals and it is confident that, provided no unexpected snags appear during testing, the hovertrain is both a practicable and an economic proposition for long distance links.

\section{Appointment}

Professor S. F. EDWARDS, University of Manchester, has been appointed by Mrs Margaret Thatcher, Secretary of State for Education and Science, to fill one of two outstanding vacancies on the University Grants Committee. His term of office will run until 1976. The other members are Sir Kenneth Berrill, chairman, Sir Robert Aitken, Professor G. A. Barnard, Professor C. E. H. Bawn, Professor J. Black, Dr G. S. Bosworth, Miss E. J. Bradbury, Professor A. J. Brown, Dr D. Cook, Professor R. C. Cross, Professor J. Cruickshank, Professor A. Davies, Professor J. Diamond, Mrs J. Floud, H. R. Galleymore, Professor N. C. Hunt, Professor D. Lewis, Professor P. G. Stein, and Professor Sir Charles StuartHarris. 